Export controls \section{Scepticism over liberality promise} Washington

THE US Department of Commerce (DoC), long the bugbear of US high technology exporters because of its allegediy inefficient processing of export licence applications, is to make substantial changes in its licensing regulations. The changes are required by recent legislation and by agreements reached with the United States' partners in COCOM, the Coordinating Committee on Multilateral export Controls*

Most recently, the department has been advertising to industry the virtues of its new "foreign availability office", intended to ensure that the United States does not restrict on national security grounds exports of high technology items that are freely available to the Eastern bloc from other sources. But, logical though this sounds, industry is sceptical of whether the office will have the desired effect

Foreign availability was supposed to be taken into account in determining whether to allow exports even before the Export Administration Amendments Act became law on $12 \mathrm{July}$, but requests for licences on these grounds usually fell on deaf ears. The new office is intended to change that. William Archey, assistant secretary for trade administration, has described the new foreign availability rules as "the dark horse" of export regulations.

Under the new act, after receiving an export licence application that rests on a claim of foreign availability, DoC will be allowed a grace period of 18 months during which time the US government can seek to "negotiate away" the foreign source of the item in question. The exporter has to establish that the item is available in comparable quantity and quality from a foreign source, but the burden of proof will now lie with $\mathrm{DoC}$ if it seeks to reject the applications. Even then, DoC may not be able politically to allow the export of some items demonstrably of foreign availability. Yet, even if the cynics are right, the office may still benefit industry in other ways.

Bill Maxwell, of the Computer and Business Equipment Manufacturers' Association, believes that the new office will probably succeed in preventing items being added unnecessarily to DoC's "commodity control list" of proscribed items, even if it does not manage to remove any already there. And that could be significant, especially with increasing sophistication of electronic equipment manufactured in some other "Pacific rim" countries.

The United States has consistently made the running in efforts to restrict the flow of Western high technlogy equipment to the East. Last year, DoC turned down licence applications for $\$ 300$ million worth of exports for which orders had been received, on the basis of pre-licence

checks and intelligence reports. But the United States unilaterally controls exports of some items that are not controlled by its major trading partners, which has frequently led to quarrels with allies.

One especially sensitive issue has been whether contracts legally entered into can subsequently be terminated for foreign policy reasons by invoking export controls. Despite lobbying by allied governments, nothing in the new act alters the presumption of extraterritoriality. The new act will nevertheless make it slightly harder for the President to terminate contracts for foreign policy reasons. He has to testify that the controls are necessary, and that a failure to act will lead to a "breach of the peace". (What exactly constitutes a breach of the peace is left undefined. The resulting loophole is "big enough to drive a truck through", according to one independent specialist.)

Among COCOM's more significant achievements was the agreement last year to decontrol exports to the Eastern bloc of many less-capable computers, on the grounds either that they were unlikely to be of military use or that control was im practical. COCOM merely has to be notified when exports of this sort are planned, and DoC has recently introduced regulations to allow such exports from the United States to COCOM member countries without a licence.

\section{Washington}

Comperition among states to play host to the proposed Superconducting Supercollider (SSC) has led to questions in Congress about design assumptions even before a complete conceptual design has been drawn up. When the central design group announced in September its choice of magnet design for the accelerator, most people thought the question had been settled. The group chose a high-field $\cos \theta$ design over a competing superferric design (see Nature 26 September, p.277). But Representative Joe Barton (Republican, Texas) has now carried out his own study, and concludes that the design team made a mistake.

Both designs employ superconducting magnets, but where the high-field $\cos \theta$ design relies on the arrangement of the current-carrying wires to produce a uniform magnetic field, the superferric design relies partly on steel pole pieces to shape the field and return flux efficiently. The superferric magnet design is cheaper per foot, but because it produces a lowerstrength field more magnets are needed. One important factor in a choice between the two designs is the cost of tunnelling, which depends on the terrain.

The superferric design would lead to a

\title{
Texas keeps on bidding for collider
}

But if the decontrolled items will reduce DoC's workload, other changes required by the new act will increase it. DoC has been given tight new timetables for processing licence applications: 15 days for exports to COCOM countries and 60 for most others for which COCOM review is necessary (down from 90 ). The timetables will benefit US exporters - if they are met.

Walter Olson, deputy assistant secretary for trade administration, says the United States is "pleased" by progress in COCOM, although he notes there are still areas where the United States and other members do not yet see eye to eye.

Disputed items include certain kinds of software, particularly that used in designing and fabricating semiconductors. But Olson hopes that further progress will be forthcoming, especially now that COCOM has changed its cycle of operations so that one quarter of the entire (secret) proscribed list will be reviewed each year, rather than there being a complete review every three or four years. The result, he says, will be that $D o C$ will be able to keep effective controls on those items that need to be safeguarded, while ensuring that some of the complaints that have been heard in the past about US manufacturers hobbled by harsh export controls are not repeated.

Tim Beardsley

* COCOM member countries are the United States the United Kingdom, France, Belgium, Italy, the Netherlands, Luxembourg. Norway. Denmark. Canada, West Germany, Portugal, Greece, Turkey and Japan.

larger SSC with a circumference of 100 miles, as opposed to a modest 60 miles with high-field magnets. Texas would be ideal for SSC, especially if the larger version were to be built, for the state has sites where tunelling costs would be low. Last week, at a hearing in the House of Representatives on prospects for high-energy physics, Mr Barton told Maury Tigner, head of the design group, that "it could be shown that" the superferric design would lead to a cheaper SSC. Tigner hotly disagreed, offering to debate with Barton, point by point, on the magnet selection panel's analysis. Barton said he might submit some written questions.

With Congress in a deficit-cutting mood, winning a commitment to build SSC will be difficult. The US high-energy physics community last week brought in big guns from Europe to help make their case, in the form of Herwig Schopper, director of CERN in Switzerland, and Carlo Rubbia, at present at Harvard University. Present estimates of the cost of SSC, a $40 \mathrm{TeV}$ proton-proton collider, range from $\$ 3,000$ to $\$ 6,000$ million. The design group should complete its conceptual design study in April, when more accurate cost estimates should be possible. 